\title{
Örgüt Kültür Tiplerinin Yenilikçiliğge Etkisi Örgüte Güvenin ve Örtülü Bilgi Paylaşımının Düzenleyici Rolü
}

\author{
DOI: 10.26466/opus.552817
}

\author{
*

\section{Gül Gün*} \\ * Dr.Öğr.Üyesi, Munzur Üniversitesi, İktisadi ve İdari Bilimler Fakültesi, Tunceli/Merkez \\ E-Posta: gulgun@munzur.edu.tr \\ ORCID:0000-0002-6231-3921
}

\begin{abstract}
Öz
Örgüt kültürrü, çalışanların amaçlarını, örgüt imajın yansıtarak daha sonraki mükemmellik seviyelerine ulaşmak için bağlayan unsurdur. Ĕ̆ger çevre ve örgüt kültürü bu yetenekleri beslemeye elverişli değilse (başarısızlık ve değişim korkusu, finansal kontrollere odaklanma ve riskin azaltılması) vb inovasyon örgütlerde ve bireylerde gelişemez. İnovasyon süreçlerini destekleyen bir örgüt kültürü belirsizliklerle başa çıkma yeteneğini gösterebilecek ve çevreden gelen bilgileri tehdit olarak değil de bir firsat olarak algulama yeteneğine sahip olacaktır (Szczepańska-Woszczynaa, 2015) Bilgi, yenilikçi faaliyetleri için önemli bir kaynaktır. Etkili bilgi yönetimi, bir firmanın yenilikçi kapasitesini arttırmada önemli bir yöntem olarak kabul edilir. Yenilikçilik genel olarak bilginin merkezi önemini ve özellikle yenilikçilik sistemine dahil olan farkh aktörler arasındaki bilgi transferini vurgulamaktadır; Yeni kapasitelerin ve içgörülerin geliştirilmesi, yenilikçi performansının iyileştirilmesine yol açmaktadır. eğer bu bilgi aktarılmaz ve diğer şirket çalışanlarıyla paylaşılmazsa, ne performans ne de firma inovasyon kapasitesi geliştirilemez. Bir bağlamda yenilikçilik bilginin örgüt içinde yayılması ve özümsenmesi ile değer yaratacaktır. Bu araştırmanın amacı örgüt kültür tipleri yenilikçilik ilişkisinde güven ve bilgi paylaşımının düzenleyici etkisini belirlemektir. Araştırmanın örneklemini Malatya il merkezindeki banka çalş̧anları oluşturmaktadır. Analiz sonuçlarına göre örtülü bilgi paylaşımı, örgüt kültür tiplerinin yenilikçi eğilimi etkilemesinde düzenleyici etki rolüne sahip değildir. Örgüt kültür tiplerinden destekleyici kültür tipi yenilikçilik ilişkisinde yönetsel güvenin düzenleyici rolü vardır.
\end{abstract}

Anahtar Kelimeler: Yenilikçi iş davranışı, Örgütsel Güven, Destekleyici Örgüt Kültür Tipi, Örtülü bilgi Paylaşımı 


\title{
The Effect of Organizational Culture Types on Innovation Organizational Role and Regulatory Role of Trust and Implicit Information Sharing
}

\begin{abstract}
Organizational culture is the element that connects the aims of employees to achieve their level of excellence by reflecting the organizational image. If the environment and organizational culture are not conductive to feed these talents (fear of failure and change, focus on financial controls and risk reduction etc), innovation cannot develop within organizations and individuals. An organizational culture which supports innovation processes will be able to demonstrate the ability to cope with uncertainties and to perceive information from the environment as an opportunity, not as a threat (Szczepańska-Woszczynaa, 2015) Information is an important source for innovative activities. Effective information management is accepted as an important method in increasing the innovative capacity of a company. Innovativeness emphasizes the central importance of information in general, and the transfer of knowledge between different actors involved in the innovation system in particular; development of new capacities and insights leads to the improvement of innovative performance. If this information is not transferred and shared with other company employees, neither performance nor firm innovation capacity can be developed In a certain sense, innovativeness will create a value by the distribution and assimilation of information within the organization. The aim of this study is to determine the regulatory effect of the sharing of trust and knowledge in the relationship between organizational culture and innovativeness. The sample of the study consists of bank employees in the city centrum of Malatya. According to the results of the analysis, implicit information sharing does not have a regulatory effect on the innovative tendency of the organizational culture types. Organizational trust has a regulatory role in the innovation relationship between the type of culture and the type of supportive culture.
\end{abstract}

Keywords: Innovative Business Behavior, Organizational Trust, Supporting Organization Culture Type, Tacit Information Sharing 


\section{Giriş}

İnovasyonun firma başarısındaki önemi göz önüne alındığında, örgütsel düzeyde tasarım, strateji, liderlik, insan kaynakları uygulamaları, finansal destek önde gelir fakat hepsinden, önemlisi örgüt kültürüdür (Naranjo-Valenciaa vd., 2016, s.30-41) Kültür, yenilik ve rekabet için uzun dönemli stratejik bir araçtır. Sosyal öğrenme durumu ve örgütsel yapı kültürün etkisini açıklamaktadır. Sosyal öğrenme kültürel karakteristiklerle sonraki nesillere aktarllır. Sosyal stereotipler bilgi ve teknoloji aktarım durumunu etkiler. Yenilikçi bir kültüre sahip olan ya da geliştiren bir toplum, olumsuz makro koşullara rağmen gelecekte daha iyi performans gösterebilir. Tersine, bir inovasyon karşıtı kültür, politika yapıcılar makro kondisyonları iyileştirse bile, inovasyon ve rekabet gücünü engeller (Petrakis, 2015, s.1436-143; Chen vd., 2017, s.173)

Güven, bir organizasyon içindeki yenilikler için ön şart olan yeni fikirlerin üretilmesini ve paylaşılmasını teşvik eder. Belirsizliğin yüksek olduğu durumlarda, güvenin öncü rolü oynadığına inanılmaktadır (Sankowska, 2016) Kişiler, kendilerine has farklı bilgi ve becerilerini ancak güven duydukları, paylaşımlı ve uygulamalı ortamlarda ve ortaklaşa yarar elde edebilecekleri durumlarda, yüz yüze etkileşim ile paylaşabilirler (Polat ve Arabacı, 2015 ) Bilgi paylaşımı uygulamaları, organizasyon kümesinde mevcut bilgi ve uzmanlı̆̆ın senkronizasyonu, işbirliği olarak kabul edilir (Rehman vd., 2015, s.177-202) Örgüt kültürü, paylaşılan değerler kapsamında iletişim ve karşılıklı anlayışın temelini oluşturur ve çalışan davranışını iki ana işlevi ile etkiler: içsel entegrasyon ve koordinasyon (Naranjo-Valencia vd., 2016, s.30-41) Örgüt kültürünün yenilikçi eğilime etkisinde örgütsel güven ve bilgi paylaşımının düzenleyici rolü olup olmadığı araştırmanın temel sorunsalını oluşturmaktadır. Bu amaç doğrultusunda aşağıdaki araştırma problemlerine cevap aranmıştır: 1. Örgüt kültür tipleri (bürokratik kültür) ile yenilikçi eğilim arasında örgüte güven ve bilgi paylaşımı düzenleyici etki göstermekte midir?

2. Örgüt kültür tipleri (yenilikçi kültür) ile yenilikçi eğilim arasında örgüte güven ve bilgi paylaşımı düzenleyici etki göstermekte midir?

3. Örgüt kültür tipleri (destekleyici kültür) ile yenilikçi eğilim arasında örgüte güven ve bilgi paylaşımı düzenleyici etki göstermekte midir? 


\section{Örgüt Kültür Tipleri, Yenilikçilik Eğilimi, Örgüte Güven ve Örtülü Bilgi paylaşımı ile ilgili Yazın Taraması}

\section{Örgüt Kültürü ile Yenilikçilik İlişkisi}

Örgütlerin uzun dönem içerisinde çevrelerinde yaşanan değişime uyum sağlayabilmeleri, rekabet üstünlüklerini koruyarak sürdürülebilir bir piyasa konumu elde etmeleri ve bu bağlamda yeniliklerin ortaya çıkmasını olanaklı kılan örgütsel süreçlerin geliştirilmesi buna uygun bir örgüt yapısının ve kültürünün tasarlanmasını da gerektirmektedir (Özkan ve Turunç, 2015, s.339)

Örgüt kültürü, çalışanların amaçlarını, örgüt imajını yansıtarak daha sonraki mükemmellik seviyelerine ulaşmak için bağlayan unsurdur. Eğer çevre ve örgüt kültürü bu yetenekleri beslemeye elverişli değilse (başarısızlık ve değişim korkusu, finansal kontrollere odaklanma ve riskin azaltılması ) vb inovasyon örgütlerde ve bireylerde gelişemez. İnovasyon süreçlerini destekleyen bir örgüt kültürü belirsizliklerle başa çıkma yeteneği gösterebilecek ve çevreden gelen bilgileri tehdit olarak değil de bir fırsat olarak algılama yeteneğine sahip olacaktır (SzczepańskaWoszczynaa, 2015) Organik örgüt yapıları ürün, servis ve teknoloji alanlarındaki değişim anlayışlarına izin verdiğinden organizasyonların yeniliğini kolaylaştırmaktadır (Green ve Cluley, 2014) Örgüt kültürü ve örgütsel yenilikçilik arasında pozitif bir ilişkinin var olduğu çeşitli araştırmalarda da öne sürülmektedir $\mathrm{Bu}$ anlamda örgüt kültürü genel olarak yenilikçiliği destekleyebilen bir kavram olarak kabul görmektedir (Özkan ve Turunç, 2015; Naranjo-Valencia vd., 2016, s.30-41; Szczepańska-Woszczynaa, 2015)

Malezya'da bir Kamu Yüksek Öğretim Kurumunda (PIHE) öğrenen örgüt kültürü düzeyinin örgütsel performans ve örgütsel yenilikçilik ile ilişkisinin araştırıldığı çalışmada (Hussein vd., 2016) tüm değişkenler arasında anlamlı pozitif ilişki olduğunu göstermektedir. Sürekli öğrenme, örgütsel performansla en yüksek korelasyona sahipken, işbirliği ve takım öğreniminin örgütsel yenilikçilik ile yüksek derecede ilişkili olduğu bulunmuştur 
Chen vd (2017, s.173) çalışmalarında ulusal kültürün kurumsal yenilikçilik üzerinde önemli etkisinin olduğu özellikle yüksek seviyede bireysellik durumunun patent oluşturmada ve ar-ge çalışmalarını yenilikçi çıktılara ulaştırmada etkili olduğu, belirsizlikten kaçınmanın yüksek olduğu yerlerde ise önemsiz patentlerin oluşturulduğu ve ar-ge çalışmalarında daha az gider oluşturdukları görülmektedir.

Lau ve Ngo (2004) yılı çalışmalarında örgüt kültürünün insan kaynakları sistemi ve ürün yenilikçiliği arasında aracılık ettiği tespit edilmiştir.

Shahzad ve Shahbaz (2017 ) Pakistan'ın yazılım endüstrisinde örgüt kültürü ve yenilikçi performans arasındaki ilişkinin araştırıldığı çalışmada yenilik performansı ile örgüt kültürü boyutları (dış uyum, örgüt iklimi, esneklik ve değişime destek, takım çalışması, personel güçlendirme yenilik performansı) arasında pozitif ilişki tespit edilmiştir.

Naranjo-Valencia vd., (2016)' nin çalışmasında İspanyadaki şirketlerde örgüt kültürü yenilikçilik ve performans arasındaki bağlantıların çalışıldığı araştırmada yenilikçiliğin örgüt kültürü ve performans arasında aracılık ettiği adhokrasi kültürünün yenilikçilik ve performansı pozitif yordadığı hiyerarşi kültürünün ise negatif yordadığ 1 çalışmada tespit edilmiştir.

Kostis vd., (2018) kültürel değişim ve yenilikçi performans arasındaki ilişkinin araştırıldığı çalışmada kültürel değişimin (kontrol, iş ahlakı, güven, dürüstlük) inovasyon üzerinde pozitif etkili olduğu itaat değişkenin ise negatif etkili olduğu tespit edilmiştir.

Shanker vd.,(2017) ‘nin Malezyadaki şirketlerde çalışan 202 yönetici ile yapılan çalışmasında yenilikçi iş davranışının örgüt iklimi ve örgütsel performans arasında aracılık ettiği tespit edilmiştir.

Verdu-Jover vd., 2018 çalışmasında adaptasyon kültürü ve ürün servis yenilikçiliği ilişkisini ele alan çalışmada yapısal esneklik ve sürekli öğrenmenin adaptif bir kültür oluşturarak ürün/hizmet inovasyon sonuçlarını pozitif etkilediği tespit edilmiştir.

Yenilikçi örgüt kültürü elde etmede aynı seviyedeki endüstrilerin benzerlikleri ve farklılıklarının Alexe ve Alexe'nin (2017) araştırdığı çalışmada IT\&C endüstrisinin otomotiv endüstrisine göre yenilikçi örgüt kültürü oluşumuna daha fazla önem verildiği tespit edilmiştir. 
Szczepańska-Woszczynaa (2015) örgüt kültürü, liderlik ve inovasyon arasındaki ilişkiyi incelediği çalı̧̧mada inovasyonun vizyoner liderlik ve destekleyici kültürle ilişkili olduğu bilgisini desteklemektedir. Bu çalışmalar dikkate alındığında bu çalışma için aşağıda yer alan hipotezler geliştirilmiştir.

- H1: Bürokratik kültür tipi ile yenilikçi eğilim arasında ilişki vardır

- H2: Yenilikçi kültür tipi ile yenilikçi eğilim arasında ilişki vardır

- H3: Destekleyici kültür tipi yenilikçi eğilim arasında ilişki vardır

\section{Güven ile Yenilikçilik İlişkisi}

Örgütsel güvenin nasıl tanımlanacağı konusunda evrensel olarak kabul edilmiş bir standart yoktur. Ancak, bazı tanımlar diğerlerinden daha sık alıntılanmaktadır. "güven" terimini, başkalarına karşı savunmasız olma istekliliğini ve güvenilirlik algılarıyla ilgili risk alma niyetini belirtmektedir Bu isteklilik, bir kuruma atıfta bulunabilecek yetenek, dürüstlük ve yardımseverlik değerlendirmelerinden kaynaklanmaktadır. Güven, bir organizasyon içindeki yenilikler için kültür oluşturur ve bunun yanı sıra olumsuz yargıları askıya aldığına ve diğer tarafça istismar edilme riskini azalttı̆̆ına inanılır. Yüksek belirsizlik ve yüksek kırılganlıkta, güvenin öncü rolü oynadığına inanılmaktadır. Yenilikçi süreçleri karakterize eden, öngörülemeyen potansiyel sonuçlar ve belirsizlik karşısında, psikolojik güvenlik hissi üretir. Güven, örgüt içi güçlendirme ile birlikte inovasyon süreçleri için ön şart olan yeni fikirlerin üretilmesini ve paylaşılmasını teşvik eder (Sankowska, 2016) Sosyal değişim teorisi bağlamında çalışanlar arasındaki güvensizlik, etkili bilgi paylaşımının önündeki bir engeldir ve organizasyonun her bir üyesinin etkin bilgi paylaşımı sağlamak için birbirleriyle iletişim kurmaları gerekmektedir (Jones, 2017, s.4).

Çalışanlar arasında güven, yenilikçi bir organizasyon içinde başarılı bir bilgi paylaşımının önemli bir unsurudur (Jones, 2017, s.4) Güven, diğer kişilere karşı risk alma ve hassasiyetli olmayı simgelemektedir. Güvenilirlik isteklilik yetenek, bütünlük ve iyilik değerlerinden kaynaklanmaktadır. Güven organizasyon içinde riskin yavaşlatılması, yüksek belirsizlik ve hassas durumlarda yenilikler için bir kültür inşa eder (Sankowska, 2016, s.96) Güven, kuruluşlar arasındaki sınırları ortadan kaldırır ve ortak çıkarların geliştirilmesine yardımcı olarak, firmanın karşılıklı bilgi 
alışverişinin derinliğini, genişliğini ve verimliliğinin arttırmasını sağlar. Aynı zamanda firmaların daha derin veya daha geniş bir yelpazedeki bilgiyi paylaşmalarını, değerli kaynakları sinerjik bir şekilde birleştirmelerini ve sözleşmeden korunma gereksinimlerinin azaltmalarını sağlar.

Knack ve Keefer (1997), düşük güvenin inovasyon yeteneğini engelleyebileceğini belirtmektedir. Güven, fiyat koyması zor ancak bir firmanın sorunları çözme ve belirsiz durumlarda rekabet etme yeteneğini güçlendiren bilgi ve kaynak alışverişini kolaylaştırır. Güvenin bu yararları, yeni fikirlerin inovasyonun geliştirilmesine yardımcı olmak için sorunsuzca akabileceği bir ortam yaratılmasına katkıda bulunur. Organizasyonlar arası güven, inovasyon kabiliyetini geliştirmek için gerekli işbirlikçi durumların ve çevrenin oluşturulmasını etkileyebilecektir. Sako ve Helper (1998) ve Dyer ve Chu (2003), güvenin yeni ürün geliştirmede öğrenmeyi, sürekli gelişmeyi ve bilgi paylaşımını nasıl desteklediğini göstermektedir. İşletmelerde daha fazla bilgi paylaşımı daha düşük maliyetlere, daha hızlı gelişime ve gelişmiş ürün / süreç yenilik uygulamalarına katkıda bulunur. Güven, firmaların işbirliği sürecinde maliyet ve riskleri azalttığından inovasyon yeteneğinin gelişiminde önemli görülmektedir (Delbufalo, 2017, s.1165-1176).

Güven, risk korkusunu azaltır ve yenilikçi işbirliğinin kabülünü belirsizlik ortamında artırır. Güven, tedarikçilerin yeni durumlarla bağlantılı stresi yönetmelerini ve edindikleri bilgileri ortaklarıyla birlikte yeni bilgiler geliştirmek için kullanma çabalarını daha iyi konsantre etmelerini sağlar (Delbufalo, 2017, s.1165-1176)

Ampirik bulgularda güven türleri ile inovasyon süreci arasında ilişki olduğu ortaya konmuştur (Murphy, 2002; Ruppel ve Harrington, 2000; Krot ve Lewicka, 2011 ) Genel olarak, güvenin yenilikçiliği olumlu yönde etkilemesi beklenmektedir (Sankowska, 2016). Sankowska (2016) çalışmasında örgütsel güvenin pazar konumunu etkilemesinde yenilikçilik ve örgütsel etkililiğin aracı rolü adlı çalışmasında örgütsel güvenin piyasa pozisyonu üzerinde yenilikçilik ve örgütsel etkililiğin aracı rolü olduğunu tespit etmiştir.

Güvenin topluluklararası işbirliği ile ürün inovasyon performansı arasında aracılık etkisinin incelendiği çalışmasında; sonuçlar, daha fazla tedarikçi katılımının sadece tasarım performansını güçlendirmeye hizmet 
ettiğini, müşteri ve üçüncü taraf katılımının da aynı anda tasarım performansını ve pazar performansını güven aracılığı ile artırdığını ortaya koymaktadır. (Lai vd., 2011, s.65-74)

Örgütsel güven pazar konumunu nasıl etkiler: yenilikçiliğin ve operasyonel verimliliğin arabuluculuk rolü adlı çalışmada (Sankowska, 2016) örgütsel güven ile operasyonel verimlilik arasında yenilikçiliğin aracı rolü olduğu yenilikçilik ve piyasa pozisyonu arasında operasyonel verimliliğin aracılık ettiği tespit edilmiştir. Literatürdeki bilgiler ışığında aşağıdaki hipotez geliştirilmiştir.

H4: Güven ile yenilikçi eğilim arasında ilişki vardır

\section{Bilgi Paylaşımı Yenilikçilik İlişkisi}

Yaratıcılığa yol açan ikinci önemli başarı faktörü yenilik ve bilgi paylaşımıdır. Organizasyondaki bilgi birikimi örgüt kültürünün içinde yer alır. Örgütlerde bilgi birikiminin paylaşımı ile firma performansının yanısıra üretim maliyetlerinde düşüş yaşanır (Kremer vd., 2019, s.62) Bilgi, inovasyon faaliyetleri için önemli bir kaynaktır. Etkili bilgi yönetimi, bir firmanın inovasyon kapasitesini arttırmada önemli bir yöntem olarak kabul edilir. İnovasyon sistemleri teorisi, genel olarak bilginin merkezi önemini ve özellikle inovasyon sistemine dahil olan farklı aktörler arasındaki bilgi transferini vurgulamaktadır; Yeni kapasitelerin ve içgörülerin geliştirilmesi, inovasyon performansının iyileştirilmesine yol açmaktadır (Madhavan ve Grover, 1998) eğer bu bilgi aktarılmaz ve diğer şirket çalışanlarla paylaşılmazsa, ne performans ne de firma inovasyon kapasitesi geliştirilemez (Hamdoun vd.,2018, s.759-770) Bilgi paylaşımı açık ve örtük bilgi olarak bilinen iki geniş bilgi kategorisini açıklar. Açık bilgi, bağımsız bir şekilde saklanabilen görünür, belgelenmiş, açık ve yapılandırılabilir bilgi olarak ifade edilir. Gizli bilgi (örtük bilgi), belgelenmemiş, açıkça ifade edilemeyen, açklanamayan, bilişsel düşünce ve algılara dayanan (yani, bireylerin zihinlerine gömülü deneyimler ve diğer insanlardan edinen) ve paylaşması zor olan üstü kapalı bilgi olarak tanımlanır. Bununla birlikte, açık bilginin, kelimeler veya sayılarla ölçülmesi ve kodlanması kolay, biçimsel ve sistematik bir bilgi olduğunu savunur. Bu resmi bilgi, şirket prosedürleri, yazılı kılavuzlar, iç ve dış veri 
formları dahil olmak üzere çeşitli organizasyon kaynaklarından elde edilebilir. Bu nedenle, açık ve net bilgi paylaşımı uygulamaları, daha iyi firmaların performansını ortaya çıkaran yaratıcılığı ve yeniliği geliştirmek için dağınık bilgiyi bütünleştirmeye yardımcı olmaktadır (Rehman vd., 2015, s.177-202)

Birçok çalışma bilgi yönetiminin inovasyon sürecine odaklandığı görülmektedir (Mardani, 2018) Liao ve Chuang (2006) çalışmasında bilgi yönetiminin teknik, sosyal ve süreç kaynağının inovasyon boyutları ve firma performansı arasındaki ilişkisi araştırılmıştır sonuçta teknik ve sosyal bilgi yönetim kaynağının inovasyon ve performansla pozitif ilişkili olduğu tespit edilmiştir.

Wang ve $\mathrm{Hu}$ (2017) inovasyon performans yeteneklerinde ve inovasyon faaliyetlerinde işbirliğinin etkileri: Tedarik zinciri ağlarında bilgi paylaşımı çalışmasında, bilgi paylaşımının yenilikçi işbirliği ve inovasyon performansı arasında kısmi aracı rol oynadığı tespit edilmiştir. Bilgi paylaşımı ve inovasyon performansı arasındaki pozitif ilişki firmanın yüksek inovasyon kapasitesinin en yüksek olduğu durumlarda görülmektedir.

Mardania vd., (2018) bilgi yönetimi ve inovasyon performansı arasındaki ilişkinin incelendiği çalışmada bilgi bütünleşmesinin inovasyon performansı üzerinde önemli etkisi tespit edilmiştir.

Hamdoun (2018) bilgi transferi ve organizasyonel yenilikçilik: kalite ve çevre yönetiminin etkisi adlı çalışmada ampirik araştırmanın ana bulgularında kalite ve çevre yönetiminin, bilgi aktarımı ile birlikte inovasyonla güçlü bir şekilde ilişkili olduğunu göstermektedir.

$\mathrm{Hu}$ vd., (2009) bilgi paylaşımı ve hizmet performansının konaklama takımlarında incelendiği çalışmada; bilgi paylaşımı ve hizmet performansı arasındaki ilişkide takım kültürünün aracılık ettiği tespit edilmiştir

Rehman vd., (2015)' in çalışmasında bilgi paylaşımı, bilgi yönetim stratejisi ve performans ilişkisindeki çalışmada bankalarda bilgi paylaşımı uygulamalarının performansa etkisinde sistem odaklı ve insan odaklı strateji mekanizmalarının aracılık edip etmediği araştırılmaktadır. Bulgularda, bilgi paylaşımı performans ilişkisinde insan ve sistem odaklı stratejinin açı ve örtülü bir şekilde aracılık ettiği tespit edilmiştir. Bu bilgilerden yola çıkarak;

- H5: Bilgi paylaşımı ile yenilikçi eğilim arasında ilişki vardır. 
Bütün önermeler dikkate alındığında bu çalışma için oluşturulan araştırmanın hipotezleri şu şekildedir

- H6: Bürokratik kültür tipi ile yenilikçi eğilim arasındaki ilişkide yöneticiye duyulan güven düzenleyici rolü oynayacaktir

- H7: Yenilikçi kültür tipi ile yenilikçi eğilim arasındaki ilişkide yöneticiye duyulan güven düzenleyici rolü oynayacaktır

- H8: Destekleyici kültür tipi ile yenilikçi eğilim arasındaki ilişkide yöneticiye duyulan güven düzenleyici rolü oynayacaktir.

- H9: Bürokratik kültür tipi ile yenilikçi eğilim arasındaki ilişkide örgüte duyulan güven düzenleyici rolü oynayacaktır.

- H10: Yenilikçi kültür tipi ile yenilikçi eğilim arasındaki ilişkide örgüte duyulan güven düzenleyici rolü oynayacaktır.

- H11: Destekleyici kültür tipi ile yenilikçi eğilim arasındaki ilişkide örgüte duyulan güven düzenleyici rolü oynayacaktır.

- H12: Bürokratik kültür tipi ile yenilikçi eğilim arasındaki ilişkide örtülü bilgi paylaşımı düzenleyici rolü oynayacaktır.

- H13: Yenilikçi kültür tipi ile yenilikçi eğilim arasındaki ilişkide örtülü bilgi paylaşımı düzenleyici rolü oynayacaktır.

- H14: Destekleyici kültür tipi ile yenilikçi eğilim arasındaki ilişkide örtülü bilgi paylaşımı düzenleyici rolü oynayacaktır.

\section{Araştırmanın Yöntemi}

\section{Araştırmanın Amacı, Kapsamı ve Sinırlılıkları}

Araştırmanın temel amacı bürokratik, destekleyici ve yenilikçi örgüt kültür tiplerinin yenilikçi eğilime etkisinde güven ve bilgi paylaşımının düzenleyici etkisinin olup olmadığını belirlemek araştırmanın temel konusunu oluşturmaktadır. Anketlerin toplandığı 2017 yılı için Malatya il ve ilçelerinde faaliyet gösteren bankalarda çalışan toplam 775 işgören çalışmanın anakütlesini oluşturmaktadır (https://www.tbb.org.tr) Malatya il merkezindeki 200 çalışan örneklemi oluşturmaktadır. Karagöz 
(2016) bilgilerine göre örneklem yeterlidir. Araştırmada, örneklem tespitinde basit tesadüfî yöntem uygulanmıştır. Örneklem yeterliliği açısından verilerin toplanmasında anket tekniği kullanılmıştır. Araştırmada kullanılan ölçeklerden birincisi;

Örgütsel Güven Ölçeği: Nyhan ve Marlow (1997) tarafından geliştirilen ölçeğin Demircan (2003) tarafından güvenirlik ve geçerlik çalışmaları yapılmış ve Türkiye ortamında kullanılabileceği tespit edilmiştir. Daha öncede birçok araştırmacı tarafından tercih edilen söz konusu ölçek 12 ifadeden oluşmaktadır. Ölçek “örgüte güven" ve "yöneticiye güven" olarak iki boyuttan oluşmaktadır. Ölçekte yer alan ilk 8 ifade yöneticiye güveni, sonraki 4 ifade ise örgütün kendisine duyulan güveni tespit etmeye yöneliktir. 5"li likert tipindeki ölçekte “(1) Kesinlikle katılmiyorum, (2) Katılmiyorum, (3) Kararsızım, (4) Katılıyorum , (5) Kesinlikle Katılıyorum" ifadeleri yer almaktadır. Örgütsel güven ölçeği için hesaplanan cronbach alpha katsayısı $\alpha=0,914$ 'dür.

Örgüt kültür tipleri: Örgüt kültürü, Wallach`ın (1983) bir çalışmasından uyarlanan ölçek ile değerlendirilmiştir. Ölçek, örgüt kültürünü her boyutta sekiz ifade olmak üzere bürokratik, yenilikçi ve destekleyici olarak üç alt boyutta toplam 24 ifade ile değerlendirmektedir. Ölçek Türkçe'ye Yahyagil (2004) tarafından uyarlanmıştır. Bürokratik kültür için cronbach alpha katsayısı $\alpha=0,778$, yenilikçi kültür, 0,789, destekleyici kültür 0,899, yenilikçi kültür 0,789 ‘dur.

Yenilikçi eğilimi: Yenilikçi davranış ölçeği: çalışanların yenilikçi davranışa eğiliminin ölçülmesinde Scott ve Bruce (1994) tarafından geliştirilen ölçek kullanılmıştır. Ölçek soruları altı sorudan oluşmaktadır. Altı sorudan oluşan ölçeğin Türkçe'ye uyarlanması ve uygulaması Akkoç tarafından gerçekleşmiştir. Akkoç (2012), “Gelişim kültürü ve etik iklimin yenilikçiliğe etkisinde dağıtım adaletinin rolü" adlı araştırmasında uyarladığı ölçeğin güvenirlik katsayısını $\alpha=89$ olarak belirlemiştir. Bu araştırma için belirlenen cronbach alpha değeri ise $\alpha=, 949^{\prime}$ dur. Bu değer araştırma için uygun bir sonuç olduğundan ölçeğin kullanılmasına karar verilmiştir. Soruların cevaplanmasında 5'li likert kullanılmış olup, hiç katılmıyorum 
(bir), katılmıyorum (iki), kararsızım (üç), katılıyorum (dört), kesinlikle katılıyorum (beş) puan olarak puanlandırılmıştır.

Bilgi paylaşımı davranışı ölçeği : Göksel vd., (2010) tarafından Bock vd. (2005) çalışmasından derlenerek Türkçeye adapte edilen ölçek kullanılmıştır. Ölçek 3 maddeden oluşmaktadır. Bu araştırma için belirlenen cronbach alpha değeri ise $\alpha=, 756^{\prime}$ dır. Zaman sınırlaması olmayan ölçek 5'li Likert tipinde (5) Her Zaman, Çok fazla var, (4) Genellikle, Çokça var, (3) Ara Sıra, Orta miktar var, (2) Çok Nadir, Çok Az var, (1) Hiçbir Zaman, Hiç yok şeklinde hazırlanmıştır.

\section{Araştırma Bulguları}

Tablo 1: Kişisel Bilgilerinin Dă̆ılımları

\begin{tabular}{llll}
\hline & & $\mathbf{n}$ & $\mathbf{\%}$ \\
\hline \multirow{2}{*}{ Cinsiyet } & kadın & 69 & 34,5 \\
& erkek & 131 & 65,5 \\
\hline \multirow{3}{*}{ Yaş } & $18-25$ & 42 & 21,0 \\
& $26-35$ & 100 & 50,0 \\
& 35 ve üstü & 58 & 29,0 \\
\hline \multirow{4}{*}{ Öğrenim durumu } & ilköğretim & 7 & 3,5 \\
& lise & 23 & 11,5 \\
& önlisans & 75 & 37,5 \\
& lisans & 77 & 38,5 \\
Çalışma süresi & yüksek lisans & 18 & 9,0 \\
\hline \multirow{3}{*}{ İşletmedeki çalışma süresi } & $0-1$ & 15 & 7,5 \\
& $1-5$ & 69 & 34,5 \\
& 5 ve üstü & 116 & 58,0 \\
\hline & $0-1$ & 10 & 5,0 \\
& $1-5$ & 93 & 46,5 \\
Konum & ve üstü & 97 & 48,5 \\
& müdür & 7 & 3,5 \\
& müdür yardımcısı & 33 & 16,5 \\
& operasyon servis yetkilisi & 37 & 18,5 \\
& pazarlama yetkili yardımcısı & 47 & 23,5 \\
& gişe yetkilisi & 52 & 26,0 \\
& asistan & 24 & 12,0 \\
\hline
\end{tabular}

Çalışanların \%65,5'i erkek, \%50,0'si 26-35 yaşında, \%38,5'i lisans mezunudur. Çalışanların \%58,0'i 5 yıl ve üstü süredir çalışmakta, \%48,5'i 5 yıl ve üstü süredir işletmesinde çalışmakta, $\% 26,0^{\prime}$ sı gişe yetkilisidir. 
Tablo 2: Ölçek Puanlarının Betimleyici İstatistikleri

\begin{tabular}{lllllll}
\hline & $\begin{array}{l}\text { Mini- } \\
\text { mum }\end{array}$ & $\begin{array}{l}\text { Maksi- } \\
\text { mum }\end{array}$ & $\begin{array}{l}\text { Orta- } \\
\text { lama }\end{array}$ & $\begin{array}{l}\text { Std. } \\
\text { Sapma }\end{array}$ & $\begin{array}{l}\text { Çarpık- } \\
\text { lik }\end{array}$ & Basıklık \\
\hline Yenilikçi Eğilimi & 1,71 & 5,00 & 3,78 & 0,76 & $-0,83$ & $-0,28$ \\
\hline Bürokratik Kültür & 1,88 & 5,00 & 2,86 & 0,57 & 1,05 & 1,00 \\
\hline Yenilikçi Kültür & 1,88 & 5,00 & 3,58 & 0,64 & $-0,39$ & $-0,81$ \\
\hline Destekleyici Kültür & 1,88 & 5,00 & 3,57 & 0,80 & $-0,22$ & $-1,04$ \\
\hline $\begin{array}{l}\text { Örtülü Bilgi } \\
\text { Paylaşımı Davranışı }\end{array}$ & 2,00 & 5,00 & 3,89 & 0,78 & $-0,67$ & $-0,57$ \\
\hline $\begin{array}{l}\text { Yöneticiye Duyulan Gü- } \\
\text { ven }\end{array}$ & 1,88 & 5,00 & 3,74 & 0,86 & $-0,90$ & $-0,48$ \\
\hline $\begin{array}{l}\text { Örgüte Duyulan } \\
\text { Güven }\end{array}$ & 1,00 & 5,00 & 3,63 & 0,98 & $-0,71$ & $-0,64$ \\
\hline
\end{tabular}

Çalışanların; yenilikçi eğilim puan ortalaması 3,78 $\pm 0,76$ 'dır. Çalışanların

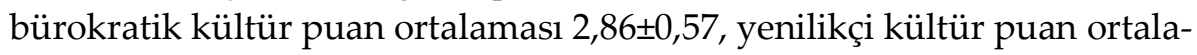

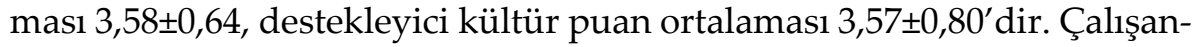

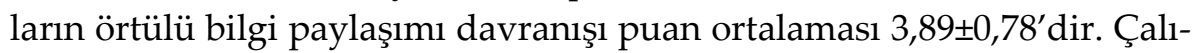
şanların yöneticiye duyulan saygı puan ortalaması 3,74 $\pm 0,86$, örgüte duyulan güven puan ortalaması 3,63 $\pm 0,98^{\prime}$ dir.

Tablo 3: Yenilikçi Eğilim Puanının Diğer puanlar ile İlişkisi

\begin{tabular}{lll}
\hline \multirow{2}{*}{ Bürokratik Kültür } & & Yenilikçi Eğilim \\
\hline \multirow{2}{*}{ Yenilikçi Kültür } & $\mathrm{r}$ &, $151^{*}$ \\
& $\mathrm{p}$ &, 032 \\
\hline \multirow{2}{*}{ Destekleyici Kültür } & $\mathrm{r}$ &, $613^{* *}$ \\
& $\mathrm{p}$ &, 000 \\
\hline \multirow{2}{*}{ Örtülü Bilgi Paylaşımı Davranı̧̧ı } & $\mathrm{r}$ &, $592^{* *}$ \\
\hline \multirow{2}{*}{ Yöneticiye Duyulan Güven } & $\mathrm{p}$ &, 000 \\
\hline \multirow{2}{*}{ Örgüte Duyulan Güven } & $\mathrm{r}$ &, $516^{* *}$ \\
& $\mathrm{p}$ &, 000 \\
\hline
\end{tabular}

${ }^{* *} p<0,01,{ }^{*} p<0,05$ anlamlı ilişki var, $p>0,05$ anlamlı ilişki yok, korelasyon katsayısı güç düzeyleri; $0<r<0,299$ zayıf, $0,300<r<0,599$ orta, 0,600<r<0,799 güçlü, 0,800<r<0,999 çok güçlü.

Yapılan pearson korelasyon analizi sonuçlarına göre; yenilikçi eğilim puanı ile bürokratik kültür $(\mathrm{r}=0,151)$ puanı arasında pozitif yönlü zayıf ilişki, 
destekleyici kültür $(\mathrm{r}=0,592)$, örtülü bilgi paylaşımı davranışı $(\mathrm{r}=0,516)$ puanları ile arasında pozitif yönlü orta kuvvetli ilişki, yenilikçi kültür $(\mathrm{r}=0,613)$, yöneticiye duyulan güven $(\mathrm{r}=0,691)$, örgüte duyulan güven $(\mathrm{r}=0,699)$ puanları ile arasında pozitif yönlü güçlü ilişki bulunmaktadır $(\mathrm{p}<0,05)$.

Tablo 4: Örgüte Güven ve Bilgi Paylaşımının Örgüt külttür tipleri ile İlişkisi

\begin{tabular}{llllll}
\hline & & $\begin{array}{l}\text { Bürokratik } \\
\text { tür }\end{array}$ & $\begin{array}{l}\text { kül- } \\
\text { Yür }\end{array}$ & $\begin{array}{l}\text { Yenilikçi } \\
\text { tül- }\end{array}$ & $\begin{array}{l}\text { Destekleyici kül- } \\
\text { tür }\end{array}$ \\
\hline Örtülü bilgi & $\mathrm{r}$ &,- 107 &, $609^{* *}$ &, $622^{* *}$ \\
paylaşımı davranış1 & $\mathrm{p}$ &, 130 &, 000 &, 000 \\
\hline \multirow{2}{*}{ Yöneticiye duyulan güven } & $\mathrm{r}$ &, $197^{* *}$ &, $710^{* *}$ &, $623^{* *}$ \\
& $\mathrm{p}$ &, 005 &, 000 &, 000 \\
\hline \multirow{2}{*}{ Örgüte duyulan güven } & $\mathrm{r}$ &, 105 &, $603^{* *}$ &, $605^{* *}$ \\
& $\mathrm{p}$ &, 140 &, 000 &, 000 \\
\hline
\end{tabular}

** $\mathrm{p}<0,01$, * $\mathrm{p}<0,05$ anlamlı ilişki var , $\mathrm{p}>0,05$ anlamlı ilişki yok , Korelasyon katsayısı güç düzeyleri; $0<\mathrm{r}<0,299$ zayıf, $0,300<\mathrm{r}<0,599$ orta, $0,600<\mathrm{r}<0,799$ güçlü, $0,800<\mathrm{r}<0,999$ çok güçlü.

Yapılan pearson korelasyon analizi sonuçlarına göre; bürokratik kültür puanı ile yöneticiye duyulan güven $(r=0,197)$ puanı arasında pozitif yönlü zayıf ilişki bulunmaktadır $(\mathrm{p}<0,05)$ yenilikçi kültür puanı ile örtülü bilgi paylaşımı davranışı $(\mathrm{r}=0,609)$, yöneticiye duyulan güven $(\mathrm{r}=0,710)$, örgüte duyulan güven $(\mathrm{r}=0,603)$ puanları arasında pozitif yönlü güçlü ilişki bulunmaktadır. Destekleyici kültür puanı ile örtülü bilgi paylaşımı davranışı $(\mathrm{r}=0,622)$, yöneticiye duyulan güven $(\mathrm{r}=0,623)$, örgüte duyulan güven $(\mathrm{r}=0,605)$ puanları arasında pozitif yönlü güçlü ilişki bulunmaktadır.

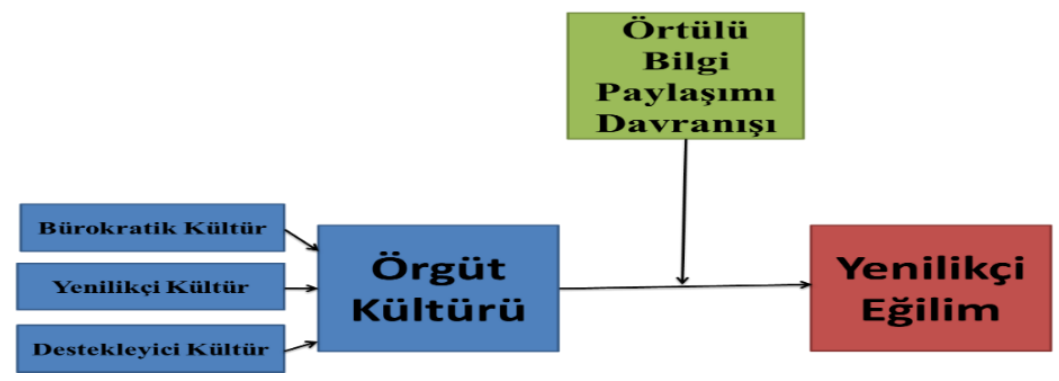

Şekil 1.Model X 
Tablo 5: Örgüt kültür tipi ve Yenilikçi Ĕ̆ilim arasındaki ilişkide Örtülü Bilgi Paylaşımı Davranışının Düzenleyiciliğine İlişkin Hiyerarşik Regresyon Analizi

\begin{tabular}{|c|c|c|c|c|c|c|}
\hline \multirow{2}{*}{ Bağımsız Değişken } & \multicolumn{3}{|c|}{ Katsayılar } & \multicolumn{3}{|c|}{ Model } \\
\hline & B & $t$ & $\mathrm{p}$ & $\mathbf{F}$ & p & $\mathbf{R}^{2}$ \\
\hline Bürokratik Kültür & 0,085 & 1,427 & 0,115 & \multirow{3}{*}{44,000} & \multirow{3}{*}{0,000} & \multirow{3}{*}{0,402} \\
\hline Yenilikçi Kültür & 0,332 & 3,040 & $0,003 *$ & & & \\
\hline Destekleyici Kültür & 0,315 & 2,950 & $0,004^{*}$ & & & \\
\hline Bürokratik Kültür & 0,130 & 2,163 & $0,032^{*}$ & \multirow{4}{*}{37,052} & \multirow{4}{*}{0,000} & \multirow{4}{*}{0,432} \\
\hline Yenilikçi Kültür & 0,232 & 2,092 & $0,038^{*}$ & & & \\
\hline Destekleyici Kültür & 0,255 & 2,405 & $0,017^{*}$ & & & \\
\hline Örtülü Bilgi Paylaşımı Davranışı & 0,230 & 3,176 & $0,002^{*}$ & & & \\
\hline Bürokratik Kültür & 0,142 & 2,298 & $0,023^{*}$ & \multirow{7}{*}{21,396} & \multirow{7}{*}{0,000} & \multirow{7}{*}{0,438} \\
\hline Yenilikçi Kültür & 0,238 & 2,102 & $0,037^{*}$ & & & \\
\hline Destekleyici Kültür & 0,255 & 2,370 & $0,019^{*}$ & & & \\
\hline Örtülü Bilgi Paylaşımı Davranışı & 0,191 & 2,464 & $0,015^{*}$ & & & \\
\hline Bürokratik * Bilgi & 0,007 & 0,112 & 0,911 & & & \\
\hline Destekleyici * Bilgi & $-0,129$ & $-1,147$ & 0,253 & & & \\
\hline Yenilikçi ${ }^{*}$ Bilgi & 0,056 & 0,503 & 0,616 & & & \\
\hline \multicolumn{7}{|l|}{ Model $2 ; \triangle F=10,086^{*}, \triangle R^{2}=0,029$} \\
\hline Model 3; $\triangle \mathrm{F}=0,728, \triangle \mathrm{R}^{2}=0,006$ & & & & & & \\
\hline
\end{tabular}

Yapılan hiyerarşik regresyon analizi sonuçlarına göre; hiyerarşik regresyon dizisinde kurulan 1. model istatistiksel olarak anlamlıdır ( $\mathrm{F}=44,000$ , $\mathrm{p}<0,05)$. Yenilikçi kültür $(\mathrm{B}=0,332)$, Destekleyici kültür, $(\mathrm{B}=0,315)$, yenilikçi eğilimi pozitif etkilemektedir $(p<0,05)$. Hiyerarşik regresyon dizisinde kurulan 2. model istatistiksel olarak anlamlıdır $(\mathrm{F}=37,052, \mathrm{p}<0,05)$. Bürokratik kültür $(B=0,130)$, yenilikçi kültür $(B=0,232)$, Destekleyici kültür $(B=0,255)$, örtülü bilgi paylaşımı davranışı $(B=0,230)$ yenilikçi eğilimi pozitif etkilemektedir $(\mathrm{p}<0,05)$.

Hiyerarşik regresyon dizisinde kurulan 3. model istatistiksel olarak anlamlıdır $(\mathrm{F}=21,396, \mathrm{p}<0,05)$. Bürokratik kültür $(\mathrm{B}=0,142)$, yenilikçi kültür $(B=0,238)$, destekleyici kültür $(B=0,255)$, örtülü bilgi paylaşımı davranışı $(B=0,191)$ yenilikçi eğilimi pozitif etkilemektedir $(p<0,05)$.

2. modele örtülü bilgi paylaşımı davranışının bürokratik kültür, destekleyici kültür, yenilikçi kültür ile etkileşiminin eklenmesiyle modelde anlamlı derecede değişim olmamıştır $(\triangle \mathrm{F}=0,728, \mathrm{p}>0,05)$ Modele katılan etkileşim değişkenleri yenilikçi eğilimi etkilememektedir $(p>0,05)$ 
Bu sonuçlara göre örtülü bilgi paylaşımı; bürokratik kültür, destekleyici kültür, yenilikçi kültür boyutlarının yenilikçi eğilimi etkilemesinde düzenleyici etki rolüne sahip değildir. Buna göre; H12, H13, H14 reddedilmiştir.

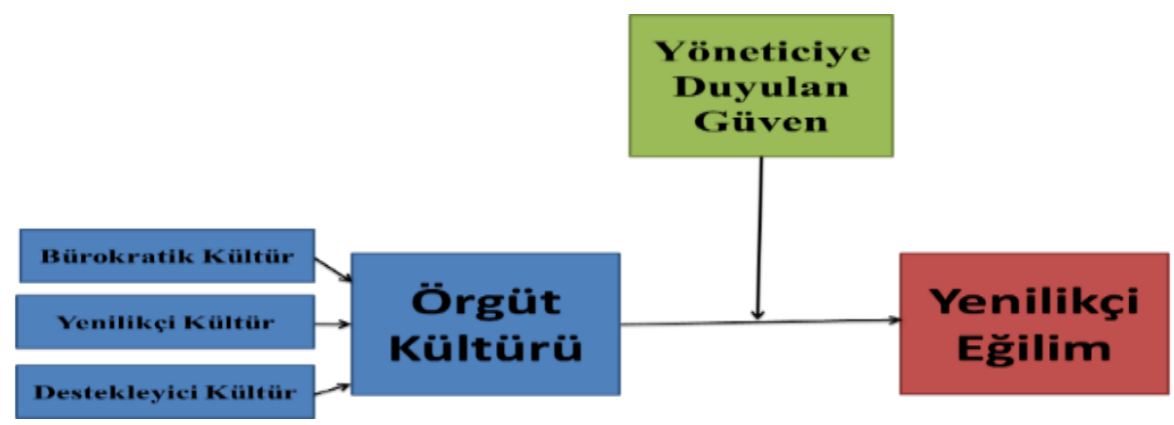

Şekil 2.Model Y

Tablo 6: Örgüt kültür tipi ve Yenilikçi Eğilim arasındaki ilişkide Yöneticiye Duyulan Güvenin Düzenleyiciliğine İlişkin Hiyerarşik Regresyon Analizi

\begin{tabular}{|c|c|c|c|c|c|c|}
\hline \multirow{2}{*}{ Bağımsız Değişken } & \multicolumn{3}{|c|}{ Katsayılar } & \multicolumn{3}{|l|}{ Model } \\
\hline & B & $t$ & p & $\mathbf{F}$ & p & $\mathbf{R}^{2}$ \\
\hline Bürokratik Kültür & 0,085 & 1,427 & 0,115 & \multirow{3}{*}{44,000} & \multirow{3}{*}{$0,000^{*}$} & \multirow{3}{*}{0,402} \\
\hline Yenilikçi Kültür & 0,332 & 3,040 & $0,003^{*}$ & & & \\
\hline Destekleyici Kültür & 0,315 & 2,950 & $0,004^{*}$ & & & \\
\hline Bürokratik Kültür & 0,045 & 0,837 & 0,404 & \multirow{4}{*}{53,455} & \multirow{4}{*}{$0,000^{*}$} & \multirow{4}{*}{0,523} \\
\hline Yenilikçi Kültür & 0,046 & 0,438 & 0,662 & & & \\
\hline Destekleyici Kültür & 0,244 & 2,535 & $0,012 *$ & & & \\
\hline Yöneticiye Duyulan Güven & 0,497 & 7,021 & $0,000^{*}$ & & & \\
\hline Bürokratik Kültür & 0,058 & 1,096 & 0,274 & \multirow{7}{*}{32,965} & \multirow{7}{*}{$0,000^{*}$} & \multirow{7}{*}{0,546} \\
\hline Yenilikçi Kültür & $-0,052$ & $-0,469$ & 0,639 & & & \\
\hline Destekleyici Kültür & 0,371 & 3,447 & $0,001^{*}$ & & & \\
\hline Yöneticiye Duyulan Güven & 0,399 & 4,615 & $0,000^{*}$ & & & \\
\hline Bürokratik * Yönetici & $-0,081$ & $-1,533$ & 0,127 & & & \\
\hline Destekleyici * Yönetici & 0,293 & 2,425 & $0,016^{*}$ & & & \\
\hline Yenilikçi * Yönetici & $-0,150$ & $-1,231$ & 0,220 & & & \\
\hline \multicolumn{7}{|l|}{ Model 2; $\triangle F=49,293^{*}, \triangle R^{2}=0,121$} \\
\hline Model 3; $\triangle F=2,571^{*}, \triangle R^{2}=0,024$ & & & & & & \\
\hline
\end{tabular}

Yapılan hiyerarşik regresyon analizi sonuçlarına göre; hiyerarşik regresyon dizisinde kurulan 1. model istatistiksel olarak anlamlıdır ( $\mathrm{F}=44,000$, 
$\mathrm{p}<0,05)$. Yenilikçi kültür $(\mathrm{B}=0,332)$, destekleyici kültür $(\mathrm{B}=0,315)$ yenilikçi eğilimi pozitif etkilemektedir $(\mathrm{p}<0,05)$.

Hiyerarşik regresyon dizisinde kurulan 2. model istatistiksel olarak anlamlıdır ( $\mathrm{F}=53,455, \mathrm{p}<0,05)$. Destekleyici kültür $(\mathrm{B}=0,244)$, yöneticiye duyulan güven $(B=0,497)$ yenilikçi eğilimi pozitif etkilemektedir $(p<0,05)$. 1 . modele Yöneticiye duyulan güven eklenmesiyle modelde anlamlı derecede değişim olmuştur $(\triangle \mathrm{F}=49,293, \mathrm{p}<0,05)$.

2. modele yöneticiye duyulan güvenin bürokratik kültür, destekleyici kültür, yenilikçi kültür ile etkileşiminin eklenmesiyle modelde anlamlı derecede değişim olmuştur $(\triangle \mathrm{F}=2,571, \mathrm{p}<0,05)$

Hiyerarşik regresyon dizisinde kurulan 3 . model istatistiksel olarak anlamlıdır ( $F=32,965, p<0,05)$. Destekleyici kültür $(B=0,371)$, yöneticiye duyulan Güven $(B=0,399)$ pozitif, destekleyici kültür * yöneticiye duyulan güven etkileşimi $(B=0,293)$ yenilikçi eğilimi pozitif etkilemektedir $(p<0,05)$.

Modele katılan bürokratik kültür * yöneticiye duyulan güven, yenilikçi kültür * yöneticiye duyulan güven etkileşim değişkenleri yenilikçi eğilimi etkilememektedir ( $p>0,05)$. Bu sonuçlara göre yöneticiye duyulan güven; bürokratik kültür, yenilikçi kültür boyutlarının yenilikçi eğilimi etkilemesinde düzenleyici etki rolüne sahip değildir.

Destekleyici kültür boyutunun yenilikçi eğilim üzerindeki etkisinde yöneticiye duyulan güvenin düzenleyici rolü vardır $(p<0,05)$ Grafikte yöneticiye duyulan güvenin en yüksek olduğu nokta yenilikçi eğilim ve destekleyici kültürün en yüksek olduğu noktadır. Buna göre H6, H7 reddedilmiş, H8 hipotezi kabul edilmiştir.

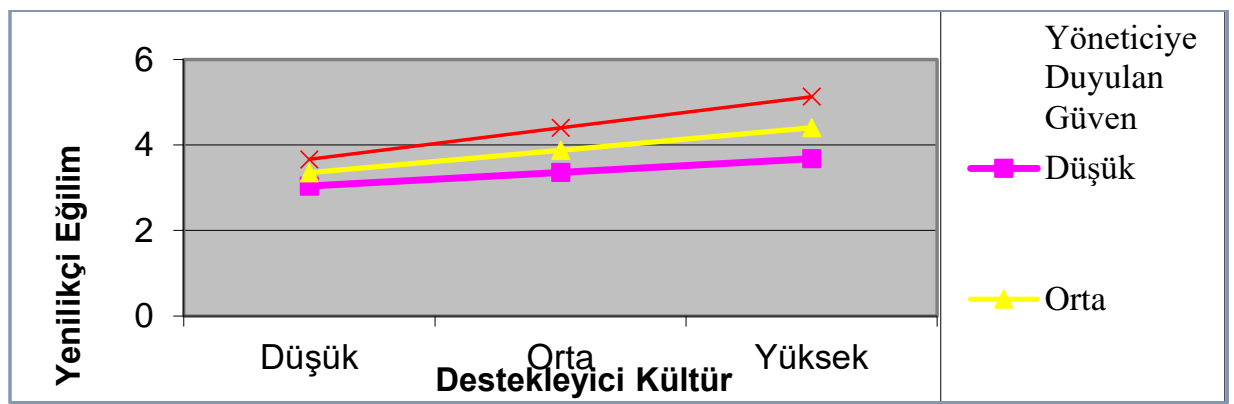

Şekil 3. Yöneticiye duyulan güvenin, destekleyici kültür ve yenilikçi eğilim ilişkisindeki düzenleyici etkisi 


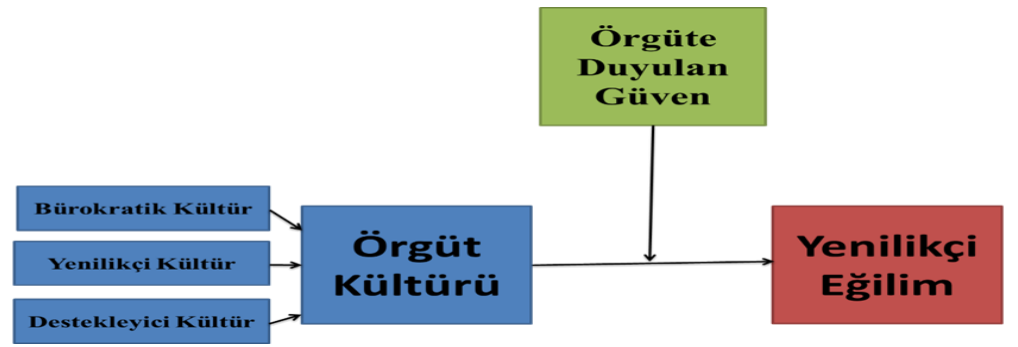

Şekil 4. Model Z

Tablo 7: Örgüt kültür tipi ve Yenilikçi Eğilim arasındaki ilişkide Örgüte Duyulan Güvenin Düzenleyiciliğine İlişkin Hiyerarşik Regresyon Analizi

\begin{tabular}{|c|c|c|c|c|c|c|}
\hline \multirow{2}{*}{ Bağımsız Değişken } & \multicolumn{3}{|l|}{ Katsayılar } & \multicolumn{3}{|l|}{ Model } \\
\hline & B & $t$ & $\mathbf{p}$ & $\mathbf{F}$ & $\mathbf{p}$ & $\mathbf{R}^{2}$ \\
\hline Bürokratik Kültür & 0,085 & 1,427 & 0,115 & \multirow{3}{*}{44,000} & \multirow{3}{*}{$0,000^{*}$} & \multirow{3}{*}{0,402} \\
\hline Yenilikçi Kültür & 0,332 & 3,040 & $0,003^{*}$ & & & \\
\hline Destekleyici Kültür & 0,315 & 2,950 & $0,004^{*}$ & & & \\
\hline Bürokratik Kültür & 0,062 & 1,185 & 0,237 & \multirow{4}{*}{59,932} & \multirow{4}{*}{$0,000^{*}$} & \multirow{4}{*}{0,551} \\
\hline Yenilikçi Kültür & 0,188 & 1,945 & 0,053 & & & \\
\hline Destekleyici Kültür & 0,134 & 1,403 & 0,162 & & & \\
\hline Örgüte Duyulan Güven & 0,498 & 8,048 & $0,000^{*}$ & & & \\
\hline Bürokratik Kültür & 0,070 & 1,355 & 0,177 & \multirow{7}{*}{36,862} & \multirow{7}{*}{$0,000^{*}$} & \multirow{7}{*}{0,573} \\
\hline Yenilikçi Kültür & 0,148 & 1,536 & 0,126 & & & \\
\hline Destekleyici Kültür & 0,163 & 1,707 & 0,089 & & & \\
\hline Örgüte Duyulan Güven & 0,454 & 6,585 & $0,000^{*}$ & & & \\
\hline Bürokratik Örgüt & $-0,105$ & $-1,956$ & 0,052 & & & \\
\hline Destekleyici Örgüt & $-0,016$ & $-0,178$ & 0,859 & & & \\
\hline Yenilikçi Örgüt & $-0,089$ & $-0,975$ & 0,331 & & & \\
\hline \multicolumn{7}{|c|}{ Model 2; $\triangle \mathrm{F}=64,775^{*}, \triangle \mathrm{R}^{2}$ değişim $=0,149$} \\
\hline Model $3 ; \triangle F=4,200^{*}, \triangle R$ & eğişim $=0,036$ & & & & & \\
\hline
\end{tabular}

Yapılan hiyerarşik regresyon analizi sonuçlarına göre; hiyerarşik regresyon dizisinde kurulan 1 . model istatistiksel olarak anlamlıdır $(\mathrm{F}=44,000, \mathrm{p}<0,05)$. Yenilikçi kültür $(\mathrm{B}=0,332)$, destekleyici kültür $(\mathrm{B}=0,315)$ yenilikçi eğilimi pozitif etkilemektedir $(\mathrm{p}<0,05)$. Hiyerarşik regresyon dizisinde kurulan 2. model istatistiksel olarak anlamlıdır ( $\mathrm{F}=59,932$, $\mathrm{p}<0,05)$. Örgüte duyulan güven $(B=0,498)$ yenilikçi eğilimi pozitif etkilemektedir $(\mathrm{p}<0,05)$. 1.modele örgüte duyulan güven eklenmesiyle modelde anlamlı derecede değişim olmuştur $(\triangle \mathrm{F}=64,775, \mathrm{p}<0,05)$. 
2. modele örgüte duyulan güvenin bürokratik kültür, destekleyici kültür, yenilikçi kültür etkileşiminin eklenmesiyle modelde anlamlı derecede değişim olmuştur $(\triangle \mathrm{F}=4,200, \mathrm{p}<0,05)$ Hiyerarşik regresyon dizisinde kurulan 3. model istatistiksel olarak anlamlıdır $(\mathrm{F}=36,862$, $\mathrm{p}<0,05)$. Örgüte duyulan güven $(B=0,454)$ yenilikçi eğilimi pozitif etkilemektedir $(\mathrm{p}<0,05)$.

Modele katılan etkileşim değişkenleri yenilikçi eğilimi etkilememektedir ( $p>0,05)$. Bu sonuçlara göre örgüte duyulan güven; bürokratik kültür, destekleyici kültür, yenilikçi kültür boyutlarının yenilikçi eğilimi etkilemesinde düzenleyici etki rolüne sahip değildir.

Hiyerarşik regresyon analizi sonuçlarına göre; H2, H3, H4, H5, H8 kabul, H1, H9, H10, H11, H12, H13, H14 reddedilmiştir

\section{Sonuç}

Organizasyonları başarıya ulaştırmada kültürün önemli bir işlevi vardır. Her organizasyonun örgütsel mükemmellik sağlama yolunda bir tür rehber olma vizyonu ve misyonu vardır. Örgüt kültürü, çalışanların amaçlarını, örgüt imajını yansıtarak daha sonraki mükemmellik seviyelerine ulaşmak için bağlayan unsurdur. Öte yandan, araştırmaların gösterdiği gibi, eğer çevre ve örgüt kültürü bu yetenekleri beslemeye elverişli değilse, inovasyon örgütlerde ve bireylerde gelişemez. Olumlu kültürel özellikler bir kuruluşa inovasyon için gerekli malzemeleri sağlayabilir (Szczepańska-Woszczynaa, 2015, s.396 ) Çalışanlar arasında güven, yenilikçi bir organizasyon içinde başarılı bir bilgi paylaşımının önemli bir unsurudur (Jones, 2017, s.4) Bilgi, yenilikçi faaliyetleri için önemli bir kaynaktır. Etkili bilgi yönetimi, bir firmanın yenilikçi kapasitesini arttırmada önemli bir yöntem olarak kabul edilir. Yenilikçilik, genel olarak bilginin merkezi önemini ve özellikle yenilikçilik sistemine dahil olan farklı aktörler arasındaki bilgi transferini vurgulamaktadır; yeni kapasitelerin ve içgörülerin geliştirilmesi, yenilikçi performansının iyileştirilmesine yol açmaktadır (Madhavan ve Grover, 1998) eğer bu bilgi aktarılmaz ve diğer şirket çalışanlarla paylaşılmazsa, ne performans ne de firma inovasyon kapasitesi geliştirilemez (Hamdoun vd.,2018, s.759-770) Güvenin azalması bilgi paylaşımının önünü tıkayan bir engel olarak ortaya çıkarken 
doğru ve net bir bilgi akışı güven hissedilen bir ortamda gerçekleşmektedir (Roberts ve O'Reilly, 1974, s.2012'den akt: Sezgin vd.,2015) Çalışmada bürokratik, destekleyici ve yenilikçi örgüt kültür tiplerinin yenilikçi eğilime etkisinde güven ve bilgi paylaşımının düzenleyici etkisinin olup olmadığı araştırılmaktadır. Çalışmanın sonucunda örtülü bilgi paylaşımı ve örgütsel güven düzeylerinin yenilikçi eğilimle pozitif ilişkili olduğu tespit edilmiştir. Bu sonuç Wang ve Hu (2017) ve Hamdoun (2018)'in çalışmasındaki sonuçlarla örtüşmektedir. Ayrıca örgüt kültür tiplerinden destekleyici ve yenilikçi kültür tipi ile yenilikçi eğilim arasında pozitif ilişki tespit edilmiştir. Bu sonuç örgüt kültürünün yenilikçi davranışı anlamlı etkilediği bulgusunu belirten çalışmalar (Szczepańska-Woszczynaa, 2015, Naronjo-Valencia vd, 2015) ile örtüşmektedir. Çalışma sonucunda banka çalışanlarının örgüte güven ve örtülü bilgi paylaşımı davranışlarının iyi derecede olduğu görülmektedir. Bu durum yenilikçiliği etkileyen önemli bir sonuç olarak görülebilir. Yapılan hiyerarşik regresyon analizi sonuçlarına göre örtülü bilgi paylaşımı davranışının bürokratik kültür, destekleyici kültür, yenilikçi kültür ile etkileşiminin eklenmesiyle modelde anlamlı derecede değişim olmamıştır. Bu sonuçlara göre örtülü bilgi paylaşımı; bürokratik kültür, destekleyici kültür, yenilikçi kültür boyutlarının yenilikçi eğilimi etkilemesinde düzenleyici etki rolüne sahip değildir. Örgüt kültür tiplerinden destekleyici kültür tipinin yenilikçilik ilişkisinde yönetsel güvenin düzenleyici rolü tespit edilmiştir.

Örgütler, değişen çevre koşullarına uyum sağlayabilmek, örgütsel performanslarını sürdürebilmek ve artırabilmek için yenilik yapma ve risk alma eğilimindedirler. Yenilik yönelimli ve risk eğilimli olabilmek ise üst yönetimin desteğine, paylaşılan bir kültür oluşturmaya, katılım ve iş birliğine imkan verilmesine en önemlisi de güvene dayalı bir örgüt yapısının oluşturulmasına bağlıdır. Bu bağlamda yenilik sürecinin önemli olduğu bankalarda yöneticilere güven konusu önem kazanmakta ve destekleyici kültür yapısıyla bu desteklenmelidir. Bundan sonraki çalışmalarda örgüt kültürü ve yenilikçiliği etkileyen örgütsel hafıza, örgütsel vazgeçme gibi faktörler aracı değişken olarak incelenip araştırılabilir. 


\title{
EXTENDED ABSTRACT
}

\section{The Effect of Organizational Culture Types on Innovation Organizational Role and Regulatory Role of Trust and Implicit Information Sharing}

\author{
Gül Gün \\ Munzur University
}

The aim of this study is to determine the regulatory impact of knowledge sharing and trust in the relationship between organizational culture types and innovativeness. The sample of the study was composed of 200 bank employees in Malatya city center. According to the results of the analysis, implicit knowledge sharing does not have a regulatory impact role in the influence of organizational culture types on the innovative tendency. Managerial trust has a regulatory role in the relationship between supportive culture type, which is one of organizational culture types, and innovativeness. Considering the importance of innovation in company's success, design, strategy, leadership, human resources applications, financial support at organisational level are significant, but above all, the most important is the organizational culture (Naranjo-Valenciaa et al., 2016, p.30-41) Culture is a long term strategic tool for innovation and competition. Social learning status and organizational structure explain the impact of culture. Social learning is transferred to subsequent generations through cultural characteristics. Social stereotypes affect the state of knowledge and technology transfer. A society with or developing an innovative culture may perform better in the future despite adverse macro conditions. On the contrary, even though an anti-innovation culture and policy makers improve the macro-conditions, they prevent innovation and competitiveness (Petrakis, 2015, p.1436-143; Chen et al., 2017, p.173).

Trust encourages the generation and sharing of new ideas, which is a prerequisite for innovation within an organization. Where the uncertainty is high, trust is believed to play a leading role (Sankowska, 2016). Individuals can share their unique knowledge and skills only in face-to-face interaction where they are confident, in shared and applied environments and where they can benefit jointly (Polat and Arabac1, 2015). Information sharing practices, synchronization of existing knowledge and expertise in the organization 
cluster are considered to be cooperation (Rehman et al., 2015, p.177-202). Organizational culture forms the basis of communication and mutual understanding within the shared values and affects employee behavior with two main functions: internal integration and coordination (Naranjo-Valencia et al., 2016, p.30-41). The main problematic of the research is whether organizational trust and knowledge sharing have a regulatory role in the impact of organizational culture on innovative tendency. For this purpose, the following hypotheses were created:

- H1: There is a relationship between bureaucratic culture type and innovative tendency

- $\quad \mathrm{H} 2$ : There is a relationship between the innovative culture type and the innovative trend.

- H3: There is a relationship between supportive culture type and innovative trend.

- H4: There is a relationship between trust and innovative trend.

- H5: There is a relationship between knowledge sharing and innovative trend.

- H6: Trust in the manager will play a regulatory role in the relationship between bureaucratic culture type and innovative tendency.

- $\quad$ H7: Trust in the manager will play a regulatory role in the relationship between the innovative culture type and the innovative trend.

- H8: Trust in the manager will play a regulatory role in the relationship between the supportive culture type and the innovative trend.

- H9: Trust in the manager will play a regulatory role in the relationship between bureaucratic culture type and innovative tendency.

- H10: Trust in the manager will play a regulatory role in the relationship between the innovative culture type and the innovative trend.

- H11: Trust in the organization will play a regulatory role in the relationship between the supportive culture type and the innovative trend.

- H12: Implicit knowledge sharing will play a regulatory role in the relationship between bureaucratic culture type and innovative tendency.

- H13: Implicit knowledge sharing will play a regulatory role in the relationship between the innovative culture type and the innovative trend. 
- H14: Implicit knowledge sharing will play a regulatory role in the relationship between the supportive culture type and the innovative trend.

Reliability and validity studies of Organizational Trust Scale, which is one of the scales used in the research and was developed by Nyhan and Marlowe (1997), were made Demircan (2003), and it was determined that it can be used in Turkey. This scale, which was previously preferred by many researchers, consists of 12 expressions. The scale consists of two dimensions as "trust in the organization" and "trust in the manager." The first 8 statements in the scale were designed to determine the trust in the manager and the next 4 statements were designed to determine the trust in the organization itself. Types of organizational culture; organizational culture was assessed using a scale adapted from a study by Wallach (1983). The scale evaluates the organizational culture with a total of 24 statements in three sub-dimensions as bureaucratic, innovative and supportive, including eight statements in each dimension. The scale was adapted to Turkish by Yahyagil (2004). The Cronbach's alpha coefficient for bureaucratic culture was $\alpha=0.778$, for Innovative culture 0.789, for Supportive culture 0.899; the scale developed by Scott and Bruce (1994) was used to measure the innovative tendency and employees' inclination towards innovative behavior. The scale consist of six questions. The scale, which consisted of six questions, was adapted Turkish and applied by Akkoç. Akkoç (2012) determined the reliability coefficient of the scale as $\alpha=89$ adapted in his research titled "The role of distribution justice in the impact of development culture and ethical climate on innovation."

The Cronbach's alpha value determined for this research is $\alpha=.949$. As this value was suitable for the research, the scale was decided to be used in the research. Knowledge sharing behavior scale; the scale that was adapted to Turkish by Göksel et al. (2010) by compiling the study of Bock et al. (2005) was used. It consists of 3 items. The Cronbach's alpha value determined for this research is $\alpha=.756$.

$65.5 \%$ of the employees are male, $50.0 \%$ are between $26-35$ years old, $38.5 \%$ have bachelor's degree. $58.0 \%$ of the employees have been working for 5 years and above, $48.5 \%$ have been working in their own enterprise for 5 years and above, and $26.0 \%$ are tellers. Response of Innovative Trend to the Variables and Regulatory Impact of the Trust in the Manager; according to the results of hierarchical regression analysis, the first model established in the hierar- 
chical regression sequence is statistically significant $(F=44.000, p<0.05)$. Innovative culture $(B=0.332)$ and supportive culture $(B=0.315)$ positively affect the innovative tendency $(\mathrm{p}<0.05)$. The second model established in the hierarchical regression sequence is statistically significant $(F=53.455, p<0.05)$. Supportive culture $(B=0.244)$ and trust in the manager $(B=0.497)$ positively affect the innovative tendency $(\mathrm{p}<0.05)$. There was a significant change in the model with the addition of trust in the manager $(\triangle F=49.293, p<0.05)$.

In the second model, there was a significant change after adding the interaction of trust in the manager with bureaucratic culture, supportive culture and innovative culture $(\triangle \mathrm{F}=2.571, \mathrm{p}<0.05)$.

The third model established in the hierarchical regression sequence is statistically significant $(F=53.455, p<0.05)$. Supportive culture $(B=0.371)$ positively affects the trust in the manager $(B=0.399)$, the interaction between supportive culture* and trust in the manager $(B=0.293)$ positively affect the innovative tendency $(\mathrm{p}<0.05)$.

The variables of bureaucratic culture * trust in the manager interaction and the innovative culture ${ }^{*}$ trust in the manager that are included in the model do not affect the innovative tendency ( $p>0.05)$. According to these results, trust in the manager has no regulatory impact role in the influence of bureaucratic culture and innovative culture dimensions on innovative tendency. We can say that the negative significant effect of the interaction between supportive culture dimension and trust in the manager has a regulatory role. In the graph, trust in the manager has the role of regulatory effect under the influence of the innovative tendency of the supportive culture dimension. Innovative system theory emphasizes the central importance of information in general, and the transfer of knowledge between different actors involved in the innovation system in particular; development of new capacities and insights leads to the improvement of innovative performance (Madhavan and Grover, 1998); if this information is not transferred and shared with other company employees, neither performance nor firm innovation capacity can be developed (Hamdoun et al., 2018, p.759-770). While the decrease in trust emerges as an obstacle blocking knowledge sharing, a correct and clear information flow takes place in an environment where there is trust (Roberts and O'Reilly, 1974, pp. 2012: cited by Sezgin et al., 2015). The study investigates whether or not trust and knowledge sharing have a regulatory impact on the influence of bureaucratic, supportive and innovative organizational culture types on the innovative tendency. According to these results, implicit knowledge sharing 
has no regulatory impact role on the influence of bureaucratic culture, supportive culture, and innovative culture dimensions on the innovative tendency. Regulatory role of managerial trust was determined in the relationship between the organisational culture type supportive culture and innovativeness. Being innovation-oriented and risk-prone depends on the support of the top management, the creation of a shared culture, enabling participation and cooperation and most importantly the formation of a trust-based organizational structure. In this context, trust in managers becomes important in the banks where innovation process is important and this should be supported by supporting culture structure. Innovativeness emphasizes the central importance of information in general, and the transfer of knowledge between different actors involved in the innovation system in particular; development of new capacities and insights leads to the improvement of innovative performance (Madhavan and Grover, 1998); if this information is not transferred and shared with other company employees, neither performance nor firm innovation capacity can be developed (Hamdoun et al., 2018, p.759-770). While the decrease in trust emerges as an obstacle blocking knowledge sharing, a correct and clear information flow takes place in an environment where there is trust (Roberts and O'Reilly, 1974, pp. 2012: cited by Sezgin et al., 2015). The study investigates whether or not trust and knowledge sharing have a regulatory impact on the influence of bureaucratic, supportive and innovative organizational culture types on the innovative tendency. According to these results, implicit knowledge sharing has no regulatory impact role on the influence of bureaucratic culture, supportive culture, and innovative culture dimensions on the innovative tendency. Regulatory role of managerial trust was determined in the relationship between the organisational culture type supportive culture and innovativeness. Being innovation-oriented and riskprone depends on the support of the top management, the creation of a shared culture, enabling participation and cooperation and most importantly the formation of a trust-based organizational structure. In this context, trust in managers becomes important in the banks where innovation process is important and this should be supported by supporting culture structure.

\section{Kaynakça / References}

Akkoç, İ. (2012). Gelişim kültürü ve etik iklimin yenilikçiliğe etkisinde dağıtım adaletinin rolü. Uluslararası Alanya İşletme Fakültesi Dergisi, $4(3), 45-60$. 
Alexe, C.-G. ve Alexe, C-M. (2017). Similarities and differentiations at the level of the industriesin acquiring an organizational culture in innovatio., Procedia Manufacturing, 22 , 317-324.

Chen, Y., Podolski, E.J., Veeraraghavan, M.(2017), National culture and corporate innovation, Pacific- Basin Finance Journal, 43, 173-187.

Delbufalo, E. (2017). The effects of suppliers' trust on manufacturers' innovation capability: an analysis of direct versus indirect relationships. Production Planning $\mathcal{E}$ control, The Management of operation, 28(14), 11651176.

Demircan, N. (2003), Örgütsel güvenin bir ara değişken olarak örgütsel bağl1lık üzerindeki etkisi: eğitim sektöründe bir uygulama. Yayınlanmamış doktora tezi, Gebze İleri Teknoloji Enstitüsü Sosyal Bilimler Enstitüsü, Gebze.

Dyer, J. H., ve W. Chu. (2003) The role of trustworthiness in reducing transaction costs and improving performance: Empirical evidence from the United States, Japan, and Korea. Organization Science, 14 (1), 57-68.

Göksel, A., Aydıntan, B. ve Bingöl, D. (2010). Örgütlerde bilgi paylaşım davranışı: Sosyal sermaye boyutundan bir bakış. Ankara Üniversitesi SBF Dergisi, 65(4), 87-109.

Green, W., ve Cluely, R. (2014). The field of radical innovation: Making sense of organizational cultures and radical innovation, Industrial Marketing Management, 43(8), 1343-1350.

Hamdoun, M., Jabbour,C. J. C., ve Othman, H. B.(2018). Knowledge transfer and organizational innovation: Impacts of quality and environmental management, Journal of Cleaner Production, 193,759-777.

Hu, M. L. M., Horng, J. S., ve Sun, Y. H. C.(2009). Hospitality teams: Knowledge sharing and service innovation performance, Tourism $\mathrm{Ma}$ nagement, 30, 41-50.

Hussein, N., Omara, S., Noordin, F. ve Amir, I. N.(2016). Learning organization culture, organizational performance and organizational innovativeness in a public institution of higher education in Malaysia: A Preliminary Study. Procedia Economics and Finance, 37, 512 - 519.

Jones, G. E. (2017). Knowledge sharing and technological innovation: The effectiveness of trust, training, and good communication, Cogent Business $\mathcal{E}$ Management, 4(1), 1-15.

Karagöz, Y.(2016). Spss 23 ve Amos 23 uygulamal istatistiksel analizler. Ankara: Nobel Akademik Yayıncılık 
Knack, S. ve Keefer, P. (1997) Does social capital have an economic payoff? a cross-country investigation. The Quarterly Journal of Economics 112 (4), 1251-1288.

Kostis, P. C., Kafka, K. I. ve Petrakis, P. E. (2018). Cultural change and innovation performance. Journal of Business Research, Elsevier, 88(3), 306313.

Kremer, H., Villamor, I. ve Aguinis, H. (2019). Innovation leadership: Bestpractice recommendations for promoting employee creativity. Voice, And Knowledge Sharing, 62, 65-74.

Krot, K., ve Lewicka, D. (2011). Innovation and organisational trust: Study of firms in Poland. International Journal of Innovation and Learning, 10 (1), 43-59.

Lau, C-M. ve Ngo, H.-Y., (2004) The HR system, organizational culture, and product innovation, International Business Review, Elsevier, vol. 13(6), pages 685-703, December.

Lai, C-S., Chen, C-S. Chiu., C,-J. ve Pai, D-C. (2011). The impact of trust on the relationship between inter-organisational collaboration and product innovation performance. Technology Analysis \& Strategic Management, 23(1), 65-74.

Liao, C., ve Chuang, S.H.(2006). Exploring the role of knowledge management for enhancing firm's innovation and performance. Proceedings of the 39th Hawaii International Conference on System Sciences.

Mardania, A., Nikoosokhan, S., Moradi, M. ve Doustar, M. (2018). The relationship between knowledge management and innovation performance. Journal of High Technology Management Research, 29 (1), 12-26.

Madhavan, R., ve Grover, R. (1998). From embedded knowledge to embodied knowledge: New product development as knowledge management. Journal of Marketing, 62, 1-12.

Murphy, J. T. (2002). Networks, trust, and innovation in Tanzania's manufacturing sector. World Development, Elsevier, 30 (4), 591-619.

Naranjo-Valenciaa, J. C. Jiménez-Jiménez, D. ve Sanz-Valle, R. (2016). Studying the links between organizational culture, innovation, and performance in Spanish companies. Revista Latinoamericana de Psicología, $48(1), 30-41$. 
Özkan, Ö. ve Turunç, Ö. (2015). Örgüt kültürü ile yenilikçilik ilişkisinde rekabet şiddetinin düzenleyici etkisi: Savunma sanayinde bir uygulama. Süleyman Demirel Üniversitesi İktisadi ve İdari Bilimler Fakültesi Dergisi, 20 (1), 339-363.

Petrakis, P. E. Kostis, P. C. ve Valsamis, D. G. (2015). Innovation and competitiveness: Culture as a long-term strategic instrument during the European Great Recession, Journal of Business Research, Elsevier, 68 (7), 1436-1438.

Petrakis, P. E., Kostis, P. C. ve Valsamis, D. G. (2015). Innovation and competitiveness: Culture as a long-term strategic instrument during the European Great Recession. Journal of Business Research, Elsevier, 68 (7), 1436-1438.

Polat, M. ve Arabacı, B. (2015). Enformasyon kuramı bağlamında sosyal ağlar, örgütsel belirsizlik ve eğitim: Kavramsal bir analiz, Uluslararası Sosyal Araştırmalar Dergisi, 8(37), 797-809.

Rehman, W. U. 1. Ilyas, M. ve Asghar, N. (2015). Knowledge sharıng, knowledge management strategy and performance. Pakistan Economic and Social Review, 53 (2),177-202.

Ruppel, C. P., ve Harrington, S. J. (2000). The relationship of communication, ethical work climate, and trust to commitment and innovation. Journal of Business Ethics, 25 (4), 313-328.

Sako, M., and S. Helper. (1998) Determinants of trust in supplier relations: Evidence from the automotive industry in Japan and the United States. Journal of Economic Behavior \& Organization 34 (3), 387-402.

Sankowska, A. (2016). How organizational trust affects the market position: The Mediating Role of Innovativeness and Operational Efficiency, 26(61), 9-23.

Sezgin, O.B., Uçar, Z., Duygulu, E.(215), Güven, yenilikçi iş davranışı ilişkisinde bilgi paylaşımının aracılık rolü, İşletme Fakültesi Dergisi, 16 (2), $1-20$.

Shahzad, F., Xiu, G.Y. ve Shahbaz, M. (2017). Organizational culture and innovation performance in Pakistan's software industry. Technology in Society, 51, 66-67.

Shanker, R., Bhanugopan, R., Heijden, B. I.J.M V. D. ve Farrell, M. (2017), Organizational climate for innovation and organizational performance: The mediating effect of innovative work behavior. Journal of Vocational Behavior, 100, 67-77. 
Szczepańska-Woszczynaa, K. (2015), Organizational culture and innovation, Procedia Economics and Finance, 396 - 402.

Verdu-Jover, A. J. Lirios. A-S. ve Gomez-Gras, J.-M.(2018). Adaptive culture and product/service innovation outcomes. European Management Journal, 36 (3), 330-340.

Wang., C., ve Hu, O. (2017). Knowledge sharing in supply chain networks: Effects of collaborative innovation activities and capability on innovation performance. Academy of Management Proceedings, 1, 1-13.

Wallach, E.J. (1983) Individuals and organizations: The cultural match. Training and Development Journal, 37, 29-36.

https://tbb.(2017) TBB veri sistemi, www. org.tr/tr/bankacilik/banka-ve-sektor-bilgileri/banka-bilgileri/banka-ve-sube-sayilari/70 E.tarihi 27.8.2019

\section{Kaynakça Bilgisi / Citation Information}

Gün, G. (2019). Örgüt kültür tiplerinin yenilikçiliğe etkisi örgüte güvenin ve örtülü bilgi paylaşımının düzenleyici rolü. OPUS-Uluslararası Toplum Araştırmaları Dergisi, 13(19), 1864-1892. DOI: 10.26466/opus.552817 